\title{
PENGEMBANGAN LKPD BERBASIS PUZZLE UNTUK MENINGKATKAN HASIL BELAJAR IPA SISWA KELAS 8 SMPN 15 MUKOMUKO
}

\author{
REFNIL YETTI \\ SMPN 15 Mukomuko \\ e-mail : refnilmail@gmail.com
}

\begin{abstract}
ABSTRAK
Mengajak seseorang untuk bisa belajar sesuai dengan rencana yang sudah ditetapkan bukanlah hal yang mudah, apalagi setelah pandemi covid-19, banyak anak yang malas dalam belajar terutama membaca, sehingga diperlukan bahan ajar yang dapat menarik minat siswa. untuk siswa SMP yang masih dominan ingin bermain maka guru harus dapat menyediakan bahan ajar yang didalamnya ada unsur bermain sehingga siswa dapat termotivasi dalam belajar. Berdasarkan latar belakang tersebut peneliti melakukan Penelitian Pengembangan teradap LKPD berbasis Puzzle untuk meningktkan hasil belajar IPA siswa kelas VIII SMPN 15 Mukomuko pada materi Sistem Peredaran Darah manusia. Puzzle yang peneliti maksud adalah teka-teki silang. Dari hasil penelitian dan pengujian dari tim Validator peneliti mendapatkan LKPD berbasis Puzzle yang dapat digunakan setelah penilaian dari tim validator terhadap aspek sajian dengan nilai 18 pada kriteria $72 \%$ berada pada kategori cukup valid dan layak digunakan dengan revisi kecil, dan aspek Isi dengan nilai 23 pada kriteria $76 \%$ berada pada kategori valid dan layak digunakan tanpa revisi.dari penelitian ini kita mendapatkan sebuah referensi yang dapat digunakan oleh guru mata pelajaran IPA untuk mengajarkan materi sistema peredaran darah manusia.
\end{abstract}

Kata Kunci: Pengembangan , LKPD Puzzle, Hasil Belajar.

\section{ABSTRACT}

Inviting someone to be able to study according to a predetermined plan is not easy, especially after the covid-19 pandemic, many children are lazy in learning, especially reading, so teaching materials are needed that can attract students' interest. For junior high school students who still want to play dominantly, the teacher must be able to provide teaching materials in which there is an element of play so that students can be motivated in learning. Based on this background, the researchers conducted a Development Research on Puzzle-based LKPD to improve the science learning outcomes of class VIII SMPN 15 Mukomuko students on the material of the Human Circulatory System. The puzzle that the researcher means is a crossword puzzle. From the results of research and testing from the validator team, researchers got a Puzzle-based worksheet that can be used after the validator team's assessment of the presentation aspect with a value of 18 on the criteria $72 \%$ is in the category of quite valid and suitable for use with minor revisions, and the content aspect with a value of 23 on the $76 \%$ criteria are in the valid category and suitable for use without revision. From this research we get a reference that can be used by science subject teachers to teach material on the human circulatory system.

Keywords: Development, LKPD Puzzle, learning outcomes

\section{PENDAHULUAN}

Pandemi covid-19 telah memberikan perubahan disetiap sektor kehidupan, tak ketinggalan perubahan dalam kebiasaan dan gaya belajar siswa. Pembelajaran selama pandemi dilaksanakan secara daring dengan menggunakan Gadget atau laptop yang terhubung kejaringan internet, sehingga banyak siswa yang merasa tidak memiliki tanggungjawab untuk belajar, karena tidak diamati secara langsung oleh gurunya.

Setelah pandemi covid mulai menurun, pemerintah mengizinkan untuk melaksanakan kegiatan pembelajaran secara tatapmuka, maka guru banyak yang mulai menemukan masalah dalam menghadapi siswa yang belum bisa menyesuaikan kebiasaan belajar mereka untuk kembali tatapmuka dibawah bimbingan guru. Dikelas yang peneliti ajar banyak siswa yang 
tidak aktif dalam pembelajaran, banyak siswa yang tidak betah didalam kelas, banyak siswa yang tidak aktif dalam kegiatan pembelajaran, akibat ketidak aktifan siswa dalam proses pembelajaran mengakibatkan siswa tidak dapat menyimpan dalam memori untuk jangka panjang, sehingga ketika pengambilan nilai untuk satu kompetensi dasar yang sudah dipelajari banyak anak yang mendapatkan nilai dibawah KKM (kriteria ketuntasan Minimal).

Pembelajaran yang dirancang untuk mengaktifkan siswa melalui kegiatan - kegiatan yang dilakukan akan menimbulkan kesan pada diri siswa, materi yang mereka perolehpun akan membekas dan tersimpan dalam memori jangka panjang.

Upaya yang dapat dilakukan guru untuk mengatasi ketidakaktifan siswa salah satunya menyiapkan beberapa aktifitas yang dapat memancing siswa melalui Lembar Kerja yang dirancang guru dengan menambahkan puzzle atau permainan yang salah satunya berupa tekateki silang. Teka-teki silang merupakan permainan untuk mengasah otak dan konsentrasi siswa.

Pembelajaran yang dituntut oleh kurikulum 2013 salah satunya adalah pembelajaran yang berbasis aktifitas. Zubaidah dkk $(2018 ; 30)$ berbagai aktifitas dirancang dalam pembelajaran aktif untuk menarik minat belajar dan melibatkan peserta didik dalam proses pembelajaran. Pembelajaran aktif merupakan pembelajaran yang memberikan kesempatan kepada peserta didik untuk berperan aktif dalam proses pembelajaran. Dalam pembelajaran aktif tidak diharapkan lagi ada siswa yang malas membaca, atau yang malas mengekplorasi sumber belajar untuk mencari materi sesuai dengan tujuan pembelajaran yang sudah dirancang guru. Selanjutnya Zubaidah dkk (2016;30) mengatakan ciri umum dari pembelajaran aktif adalah guru berganti peran, dari peran mempresentasikan materi pelajaran menjadi seorang fasilitator dari proses tersebut.

Sehubungan dengan peran guru sebagai fasilitator dalam pembelajaran maka guru harus menyiapkan Lembaran Kerja bagi siswa agar mereka dapat aktif dalam pembelajaran yang disebut dengan Lembaran Kerja Peserta Didik (LKPD). LKPD merupakan bahan ajar yang dibuat dan disusun oleh guru berisi materia dan tugas-tugas yang akan dikerjakan siswa. Andi Prastowo (2011:205-206) menyebutkan bahwa LKPD memiliki fungsi sebagai berikut: 1 Sebagai bahan ajar yang bisa meminimalkan peran pendidik, namun lebih mengaktifkan peserta didik. 2 Sebagai bahan ajar yang mempermudah peserta didik untuk memahami materi yang diberikan. 3 Sebagai bahan ajar yang ringkas dan kaya akan tugas untuk berlatih. 4 Memudahkan pelaksanaan pengajaran kepada peserta didik.

Siswa SMP yang masih berada pada taraf perkembangan menuju remaja, masih memiliki kebiasaan bermain yang lebih dominan, maka LKPD yang akan dibuat sebaiknya harus memperhatikan kebiasaan belajar siswa yang lebih banyak bermain dari pada seriusnya, untuk itu penggunaan teka-teki silang didalam LkPD akan dapat meningkatkan keaktifan siswa dalam belajar sehingga materi yang sedang dipelajari dapat dipahami oleh siswa dan bertahan lama dalam memori siswa.

Teka-teki silang merupakan sebuah permainan mengisi kotak-kotak kosong yang sudah tersedia, dengan kata-kata sesuai pertanyaan yang diajukan. Permainan ini bertujuan untuk mengasah otak agar mengingat sesuatu hal dan dapat berkonsentrasi. Menurut Siberman (2014; 256) menggunakan teka-teki silang dapat mengundang minat dan perhatian siswa, karena pada dasarnya siswa akan senang diajak bermain. mengerjakan teka-teki silang tidak hanya melibatkan mental tetapi juga fisik siswa.

Mata pelajaran IPA di SMP mengandung tiga kelompok materi dengan ciri-ciri tersendiri, untuk materi Biologi dengan ciri-ciri; memiliki cakupan materi yang luas, banyak menggunakan bahasa latin, hal ini sangat memungkinkan guru untuk menyusun atau membuat teka-teki silang dalam LKPD yang harus dikerjakan siswa.

Sesuai dengan latarbelakang diatas peneliti tertarik dan mengadakan penelitian tentang Penggunaaan LKPD berbasis Puzzle untuk meningkatkan hasil belajar IPA siswa kelas 8 SMPN 15 Mukomuko. LKPD berbasis Puzzle ini didalamnya terdiri dari tujuan pembelajaran, ringkasan materi, kegiatan siswa dan Puzzle berupa tekateki silang yang merupakan tugas bagi siswa sesuai dengan materi Sistem peredaran darah manusia. 


\section{METODE PENELITIAN}

Penelitian ini merupakan penelitian pengembangan, karena mengembangkan Lembaran Kerja Peserta Didik (LKPD) atau bahan ajar. Adapun prosedur yang dilaksanakan dalam penelitian ini adalah mengikuti alur dari ADDIE. Sugiyono (2016:38) Alur ADDIE ini dikembangkan oleh Robert Maribe Branch. ADDIE merupakan singkatan dari analysis, design, development, dan evaluation, sehingga langkah-langkah dalam pengembangan LKPD berbasis Puzzle ini adalah sebagai berikut:

1. Analysis.

Pada tahap ini yang dilakukan peneliti adalah menganalisis situasi dan lingkungan yaitu kelas VIII SMPN 15 Mukomuko untuk memperoleh produk apa apa yang harus dikembangkan. Permasalahannya yaitu kurangnya keaktifan siswa dalam belajar dan banyak siswa yang malas membaca sumber belajar. Guru menggunakan LKPD yang kurang menarik bagi siswa.

2. Design

Merupakan kegiatan merancang suatu produk sesuai dengan kebutuhan yang ada pada lingkungan. Pada tahap ini peneliti melakukan kegiatan membuat LKPD berbasis Puzzle sesuai dengan materi yang sedang diajarkan, kemudian mengevaluasi hasil desain dengan evaluator yang penulis hubungi adalah pengawas pembina mata pelajaran IPA dan guru inti pada Musyawarah guru Mata pelajaran IPA.

3. Development

Merupakan kegiatan pembuatan serta pengujian produk yang dihasilkan. Pada tahap ini peneliti melakukan perbaikan sesuai saran dari evaluator dan mengujikan pada sekolah lain secara terbatas, kemudian menganalisis hasil uji coba tersebut dan melengkapi LKPD sesuai temuan pada kegiatan uji coba.

4. Implementation

Merupakan kegiatan menggunakan produk yang telah diuji cobakan secara terbatas. Pada tahap ini peneliti menggunakan LKPD berbasis Puzzle dikelas VIII pada materi sistem peredaran darah manusia.

Pada penelitian ini untuk melihat keaktifan dan keefektifan penggunaan LKPD berbasis Puzzle ini peneliti menggunakan Lembar observasi dan menyusun soal untuk mengukur peningkatan hasil belajar IPA dikelas VIII SMPN 15 Mukomuko. Teknik pengumpulan data yang dilakukan dalam penelitian pengembangan ini meliputi validasi LKPD oleh validator dengan kriteria valid yang dikemukakan oleh Akbar (2013): sangat valid untuk pencapaian skor $100 \%-76 \%$, cukup valid untuk pencapaian skor $75 \%-51 \%$, kurang valid untuk pencapaian skor 50\%-26\%, tidak valid untuk pencapaian skor 25\%-1\%.

\section{HASIL DAN PEMBAHASAN}

Penelitian yang telah peneliti lakukan dengan judul penggunaan LKPD berbasis Puzzle untuk meningkatkan hasil belajar siswa di SMPN 15 Mukomuko dengan prosedur yang peneliti ambil yang sesuai dengan masalah yang ada dilingkungan yaitu model ADDIE maka peneliti mendapatkan bahwa setelah peneliti menyusun LPKD berbasis Puzzle untuk materi sistem peredaran darah manusia, peneliti mendapat beberapa masukan dari evaluator tentang LKPD yang telah peneliti susun baik dari langkah-langkah kegiatan maupun dari segi tampilan maka peneliti pada akhirnya dapat membuat LKPD yang layak digunakan sebagai suber belajar yang dapat meningkatkan keaktifan siswa karena siswa diajak bermain dalam mengeklporasi materi pembelajaran secara mandiri dalam belajar yang pada akhirnya dapat meningkatkan hasil belajar IPA.

\section{Hasil}

1. Data Hasil pengujian kelayakan LKPD dari aspek sajian oleh ahli. 
Hasil Penelitian tentang pengembangan LKPD untuk aspek sajian, secara umum semua ítem yang merupakan indikator untuk sajian mendapat saran dan komentar dari validator, sebagai contoh saran dari validator terkait sajian yaitu indikator petunjuk pengerjaan LKPD, validator memberikan saran bahwa petunjuk pengejaan LKPD kurang jelas, maka sesuai saran dari validator maka peneliti menyesuaikan LKPD berbasis Puzzle untuk sesmua ítem yang dimaksud oleh validator. Sehingga diperoleh LKPD berbasis Puzzle yang valid..hasil validasi dari validator LKPD berbasis Puzzle untuk materi sistem peredaran darah manusia adalah sesuai tabel 1 dibawah ini.

Tabel 1. Hasil validasi aspek sajian LKPD berbasis Puzzle

\begin{tabular}{|c|c|c|c|c|c|}
\hline \multirow[t]{2}{*}{ No } & \multirow[t]{2}{*}{ Indikator aspek sajian LKPD } & \multicolumn{2}{|c|}{ Nilai } & \multirow{2}{*}{$\begin{array}{c}\text { Rata- } \\
\text { rata }\end{array}$} & \multirow[t]{2}{*}{ Ket } \\
\hline & & $\mathrm{V}_{1}$ & $\mathrm{~V}_{2}$ & & \\
\hline 1 & Petunjuk pengerjaan LKPD & 4 & 4 & 4 & Baik \\
\hline 2 & Rumusan tujuan pembelajaran & 4 & 4 & 4 & Baik \\
\hline 3 & Kejelasan ruang lingkup materi & 4 & 4 & 4 & Baik \\
\hline 4 & Langkah langkah kegiatan & 3 & 3 & 3 & cukup \\
\hline 5 & Pengaturan tata letak Puzzle & 3 & 3 & 3 & Baik \\
\hline \multicolumn{2}{|r|}{ Skor } & 18 & 18 & 18 & \\
\hline \multicolumn{2}{|c|}{ Skor maksimal } & 25 & 25 & 25 & \\
\hline
\end{tabular}

Berdasarkan hasil penilaian oleh validator untuk setiap indikator sajian LKPD memperoleh kriteria baik maka LKPD dapat digunakan dengan revisi kecil..

2. Data hasil pengujian kelayakan LKPD dari aspek isi

Draft awal LKPD yang diajukan kevalidator, hampir semua ítem indikator mendapat saran atau masukan dari validator. Berdasarkan saran dan masukan dari validator maka dilakukan perbaikan LKPD sehingga LKPD dikatakn valid. Contoh saran dari validator pada bagian pertanyaan pada Puzzle, kalimat soal kurang terarah, sehingga memungkinkan siswa untuk kurang memahami jawaban dari soal yang diminta, sehingga membuat siswa mengundang kegaduhan dikelas.

Tabel 2. Hasil validasi LKPD berbasis Puzzle (teka-teki silang) dari aspek kelayakan isi

\begin{tabular}{|c|c|c|c|c|c|}
\hline \multirow[t]{2}{*}{ No } & \multirow[t]{2}{*}{ Indikator aspek kelayakan isi } & \multicolumn{2}{|c|}{ Nilai } & \multirow{2}{*}{$\begin{array}{c}\text { Rata - } \\
\text { rata }\end{array}$} & \multirow[t]{2}{*}{ Ket } \\
\hline & & $\mathrm{V}_{1}$ & $\mathrm{~V}_{2}$ & & \\
\hline 1 & Kesesuaian materi dengan K13 & 4 & 4 & 4,00 & \\
\hline 2 & Isi LKPD mudah dipahami & 4 & 4 & 4,00 & \\
\hline 3 & $\begin{array}{l}\text { Aktifitas peserta didik dirumuskan } \\
\text { dengan jelas }\end{array}$ & 4 & 4 & 4,00 & \\
\hline 4 & $\begin{array}{l}\text { Puzzle (teka-teki silang) memungkinkan } \\
\text { peserta didik aktif }\end{array}$ & 4 & 4 & 4,00 & \\
\hline 5 & $\begin{array}{l}\text { Pertanyaan pada Puzzle (teka-teki silang) } \\
\text { sesuai dengan materi }\end{array}$ & 4 & 4 & 4,00 & \\
\hline 6 & $\begin{array}{l}\text { Kesesuaian materi dan puzzle (teka-teki } \\
\text { silang) dengan alokasi waktu yang } \\
\text { disedikan. }\end{array}$ & 3 & 3 & 3,00 & \\
\hline & Jumlah skor & 23,00 & 23.00 & 23,00 & \\
\hline
\end{tabular}

Berdasar tabel 2 hasil validasi oleh validator untuk setiap ítem indikator kelayakan isi maka LKPD berbasis Puzzle (teka-teki silang) yang memperoleh skor 23,00 berada pada kriteria 1 Baik ( dapat digunakan dengan revisi sedikit).

3. Hasil validasi LKPD berbasis Puzzle (teka-teki silang) ditinjau dari aspek kelayakan bahasa.

Draft awal LKPD yang diajukan ke validator mendapat saran dan komentar hampir pada semua ítem indikator, sebelum LKPD berbasis Puzzle ini dikatakan valid. Pada bagian 
kelayakan bahasa ini merupakan bagian yang banyak mendapatkan komentar dalam pertanyaan karena akan menyakut dengan kata-kata sebagai jawaban yang akan dimasukkan dalam kotakkotak teka-teki silang, jumlah huruf yang ditanya akan mempengaruhi bentuk teka-teki silang. Kemudian validator juga menyaran untuk menggunakan struktur kalimat atau kata-kata yang jelas sehingga dapat memudahkan siswa untuk menyelesaikan teka-teki silang didalam LKPD. Berdasarkan saran dan komentar dari validator maka dilakukan perbaikan sampai LKPD berbasis Puzzle ini dikatakan valid. Dimana diperoleh data dari validator sebagaimana tabel 3 dibawah ini.

\section{Pembahasan}

1. Hasil validasi LKPD berbasis Puzzle ditinjau dari aspek sajian LKPD

Berdasarkan hasil validasi dari validator terhadap draf LKPD berbasis Puzzle dilihat dari aspek sajian yang terdiri dari lima (5) indikator aspek yaitu (1) Petunjuk pengerjaan LKPD, (2) rumusan tujuan pembelajaran, (3) kejelasan ruang lingkup materi, (4) langkah-langkah kegiatan, dan (5) pengaturan tata letak puzzle sebagaimana disajikan pada tabel 4 dibawah ini tentang saran dan komentar validator.

Tabel 4. Revisi LKPD dari Aspek Sajian

\begin{tabular}{|c|l|}
\hline \multicolumn{1}{|c|}{ Aspek Sajian LKPD } & \multicolumn{1}{|c|}{ Revisi } \\
\hline a. Petunjuk Pengerjaan LKPD & $\begin{array}{l}\text { Petunjuk LKPD harus dirumuskan dengan jelas } \\
\text { dan menggunakan bahasa yang mudah dipahami } \\
\text { siswa, sehingga siswa mampu mengerjakan } \\
\text { LKPD. }\end{array}$ \\
\hline b. Rumusan tujuan pembelajaran & $\begin{array}{l}\text { Rumusan tujuan pembelajaran harus sesuai dengan } \\
\text { format ABCD (audiens, behavior, condition, } \\
\text { degree) dengan memperhatikan silabus. }\end{array}$ \\
\hline c. Kejelasan ruang lingkup materi & $\begin{array}{l}\text { Ruang lingkup materi harus jelas bagi siswa karena } \\
\text { siswa akan mengekplorasi materi dan berpengaruh } \\
\text { pada pengerjaan puzzle. }\end{array}$ \\
\hline d. Pengaturan tata letak puzzle & $\begin{array}{l}\text { Pemilihan pertanyaan pada puzzle untuk materi } \\
\text { sistema peredaran darah manusia harus } \\
\text { memperhatikan jumlah huruf, karena akan } \\
\text { berpengaruh pada bentuk puzzle (teka-teki silang) } \\
\text { yang akan dikerjakan siswa. }\end{array}$ \\
\hline
\end{tabular}

Berdasarkan saran dan komentar dari validator, maka dilakukan revisi sampai dihasilkan draf yang valid. Hasil penilaian validator dengan skor yang diperoleh $72 \%$. Menurut (Akbar, 2013) validasi materi dan media dikatakan dalam kategori "cukup valid" jika memperoleh skor $51 \%$ - 75\% ( dapat digunakan dengan revisi kecil). Dilihat dari aspek sajian pada LKPD yang peneliti kembangkan ini sesuai dengan apa yang disampaikan Prastowo (2015) bahwa "LKPD sebagai bahan ajar yang mempermudah memahami materi dan LKPD sebagai bahan ajar yang cukup ringkas dan untuk melatih peserta didik dalam mengerjakan. Dilihat dari aspek sajian LKPD ini juga sudah sesuai dengan apa yang dikemukakan oleh Rahayu (2018) "bahwa LKPD yang dapat digunakan siswa dalam proses pembelajaran harus merupakan LKPD yang siap pakai yang berisi materi-materi dan soal-soal.

2. Hasil validasi LKPD berbasis Puzzle untuk aspek isi.

Hasil validasi dari validator terhadap draft LKPD berbasis Puzzle untuk aspek isi yang terdiri dari enam (6) indikator aspek : (1) kesesuaian materi dengan Kurikulum 2013, (2) Isi LKPD mudah dipahami, (3) Aktifitas peserta didik dirumuskan dengan jelas, (4) Puzzle (tekateki silang) memungkinkan peserta didik aktif, (5) Pertanyaan pada Puzzle (teka-teki silang) sesuai dengan materi, (6) Kesesuaian materi dan puzzle (teka-teki silang) dengan alokasi waktu yang disedikan dapat disajikan sebagaiamana tabel 5 dibawah ini. 
Tabel 5. Revisi LKPD dari aspek Isi

\begin{tabular}{|ll|l|}
\hline \multicolumn{2}{|c|}{ Aspek Sajian LKPD } & \multicolumn{1}{c|}{ Revisi } \\
\hline $\begin{array}{l}\text { Kesesuaian materi dengan } \\
\text { Kurikulum 2013 }\end{array}$ & $\begin{array}{l}\text { LKPD harus sesuai dengan tuntutan Kompetensi } \\
\text { Inti dan Dasar yang telah dimuat di K13 }\end{array}$ \\
\hline - $\begin{array}{l}\text { Isi LKPD mudah dipahami } \\
\text { - } \begin{array}{l}\text { Aktifitas peserta didik } \\
\text { dirumuskan dengan jelas }\end{array}\end{array}$ & $\begin{array}{l}\text { Materi yang dibuat dalam LKPD merujuk pada } \\
\text { Buku siswa yang dipergunakan. }\end{array}$ \\
\hline $\begin{array}{l}\text { Aktifitas peserta didik harus mudah dipahami } \\
\text { siswa, seperti pada langkah awal siswa harus } \\
\text { terlebih dahulu membaca materi baik dari LKPD } \\
\text { atau dari buku siswa yang menjadi rujukan. }\end{array}$ \\
$\begin{array}{l}\text { memungkinkan peserta didik } \\
\text { aktif }\end{array}$ & $\begin{array}{l}\text { Puzzle dibuat semenarik mungkin, sesuai dengan } \\
\text { materi yang sudah didapatkan siswa sehingga } \\
\text { siswa tertarik untuk mengerjakan }\end{array}$ \\
\hline $\begin{array}{l}\text { Pertanyaan pada Puzzle (teka- } \\
\text { teki silang) sesuai dengan materi }\end{array}$ & $\begin{array}{l}\text { Pertanyaan-pertanyaan pada Puzzle harus } \\
\text { mewakili materi dan sesuai dengan tujuan } \\
\text { pembelajaran. }\end{array}$ \\
\hline
\end{tabular}

Berdasarkan validasi dari validator draft LKPD setelah dilakukan perbaikan maka memperoleh skor 76\% berada pada kategori "sangat baik". Menurut (Akbar: 2013) LKPD dikatakan Valid dengan kategori "sangat valid" dalam arti dapat digunakan tanpa revisi jika skor total $76 \%$ - 100\%. LKPD yang peneliti kembangkan ini sudah memuat aktifitas aktifitas siswa yaitu dalam menemukan materi dan mengerjakan latihan berupa teka-teki silang sesuai dengan apa yang dikatakn Said (2020) "bahwa aktifitas dalam mengerjakan Teka-teki silang membutuhkan keluasan pengetahuan dan daya ingat". Dilihat dari aspek sajian dan aspek isi maka LKPD yang peneliti kembangkan sudah memuat komponen LKPD yang dikemukakan oleh Prastowo (2014) "LKPD terdiri dari enam unsur yaitu judul, petunjuk belajar, materi pokok, informasi pendukung, tugas atau langkah kerja, dan penilaian.

\section{KESIMPULAN}

Pengembangan LKPD berbasis Puzzle ini artinya dalam LKPD ini terdapat Puzzle berupa teka-teki silang yang dapat dikerjakan siswa sambil bermain namun mereka harus mencari materi terlebih dahulu dan memahaminya kemudian menjawab pertanyaan dan mengisikan nya paa kotak kotak kosong tekateki silang yang ada pada LKPD. Berdasarkan hasil validasi yang diterima peneliti terhadap LKPD berbasis Puzzle yang dikembangkan ini yaitu sudah layak untuk digunakan sebagai salah satu referensi dalam proses pembelajaran Materi sistema peredaran darah manusia dikelas VIII. Hal ini ditunjukkan oleh penilaian validator sebesar $72 \%$ untuk aspek sajian dan nilai $76 \%$ untuk kelayakan isi, selain nilai dari validator LKPD yang telah dikembangkan ini juga sudah dikatakn efektif untuk meningkatkan hasil belajar siswa untuk digunakan berdasarkan nilai yang diperoleh oleh siswa setelah peneliti menggunakan pada proses pembelajaran di kelas VIII dimana diperoleh kenaikan hasil belajar siswa baik dari segi keaktifan siswa dalam belajar maupun dari hasil penilaian KD untuk sistema peredaran darah, sehingga LKPD ini sangat baik untuk digunakan. berikut:

LKPD yang peneliti kembangkan ini memiliki kelebihan dan kekurangan, yaitu sebagai

1. Kelebihan LKPD bebasis Puzzle.

a. LKPD ini dapat dikembang sendiri oleh guru.

b. LKPD ini dapat meningkatkan keaktifan siswa karena siswa diajak bermain mengisi kotak-kotak kosong, namun siswa terlebih dahulu harus menguasai materi yang dipelajarinya.

c. LKPD ini dapat meningkatkan minat baca siswa karena kalau siswa tidak membaca terlebih dahulu siswa susah untuk mngerjakan puzzle pada LKPD. 
d. LKPD ini dapat meningkatkan daya ingat siswa untuk waktu yang lama.

2. Kekurangan LKPD berbasis Puzzle

a. LKPD ini dikembangkan untuk materi Sistem perdaran darah

b. LKPD ini memilki teka-teki silang yang masih sangat sederhana sehingga perlu ditambah.

c. Pertanyaan-pertanyaan pada tekateki silang masih sangat sedikit.

Kelemahan dalam LKPD ini dapat diperbaiki menuju kesempurnaan seiring waktu. Peneliti menyarankan bahwa dalam mengembangkan LKPD maka sangat penting untuk memahami tahapan-tahapan pengembangan guna untuk dapat menghasil produk yang baik digunakan untuk mengatasi masalah dalam pembelajaran.

\section{DAFTAR PUSTAKA}

Akbar, Sa'dun. (2013). Instrumen Perangkat Pembelajaran. PT Remaja Rosdakarya Bandung. Arikunto, Suharsimi. (2006). Prosedur Penelitian Suatu Pendekatan Praktik. Rineka Cipta

Budimanjaya, Andi dan Said Alamsyah (2020). 95 Strategi Mengajar Multiple Intelligences. Indonesia Puataka.

Herman, A Aslim, H, 2015. Pengembangan LKPD Fisika SMA Berbasis Keterampilan Proses Sains. E Jurnal Universitas Negeri Makasar.

Mudlofir, ali dan Fatimatur,Evi Rusydiyah (2017). Desain Pembelajaran Inovatif. Raja Grafindo Persada Jakarta.

Putri, alvina Purnama Sari dan Lepiyanto, agil. eISSN 2441-9805 p ISSN 2086-4701. Pengembangan LKPD berbasis scientific Approach siswa SMA kelas X pada materi Fungi. BioEdukasi Universitas Muhammadiyah Metro.

Rahayu, dewi (2018) Pengembangan LKPD berbasis pemecahan Masalah matri bangun datar. https://media.neliti.com/media/publications/254879-pengembangan-lembar-kerjapeserta-didik-2b85297c.pdf

Sugiyono. (2019). Metode Penelitian Kuantitatif, Kualitatif, dan $R \&$ D. Alfabeta Bandung. Sugiyono. (2016). Statistika Untuk Penelitian. Alfabeta Bandung.

Yetti, Refnil. (2020). Asyiknya Belajar Biologi Dengan Teka-teki Silang. Pustaka Media Guru. Zubaidah, Siti dkk (2018). Buku Guru Ilmu Pengetahuan Alam Kelas IX. PT Gramedia. 